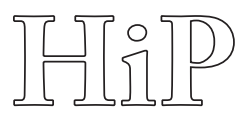

Historia i Polityka

No. $14(21) / 2015$, pp. $85-90$

ISSN 1899-5160

www.hip.umk.pl

DOI: http://dx.doi.org/10.12775/HiP.2015.022

Yuriy Mykolayovych MOROZ

Ivan Franko National University of Lviv, Ukraine

Marta DOMOCHKO

Ivan Franko National University of Lviv, Ukraine

\title{
Cooperation with Asian States as Way of Implementation of the Foreign Policy Priorities of South Sudan
}

\begin{abstract}
The article discusses the foreign policy priorities of the Republic of South Sudan in cooperation with Asian states; it provides a comprehensive study of ways of their implementation, focuses on the interests of the countries and the possible benefits of bilateral cooperation. The purpose of the article is a comprehensive study of the implementation of foreign policy priorities of South Sudan in cooperation with Asian states.
\end{abstract}

Keywords: South Sudan, Asia, India, Japan, foreign policy, foreign policy priorities, energy sector

Cooperation between South Sudan and Asian states, in particular India, Israel, Japan, Malaysia, and Russia, is characterized by the active cooperation in the energy sector, gradual development of cooperation in the field of water resources and agriculture, intensification of investment cooperation, and, on the whole, is in line with the declared foreign policy course.

South Sudan and the African continent have been the focus of attention of these countries for rather a long time. In particular, India's interest in Africa can be seen in resource wealth of South Sudan and economic interests of the Asian state, India's ambitions to intensify its participation in international relations and the desire to become a permanent member of the UN Security Council, the significance of cooperation in the Indian Ocean (which is enshrined in the Indian Maritime Doctrine and is related to pivotal role of marine deliveries ${ }^{1}$ ). On the

${ }^{1}$ D. Large, India's African Engagement, http://www.lse.ac.uk/IDEAS/publications/reports/pdf/ SR016/SR-016-Large.pdf (accessed 15.04.2015). 
other side, African states are interested in India as a developed international partner, which is relevant to the South-South vector of cooperation. Also, India serves as a good example to postcolonial Africa and is an alternative to the West.

Direct interests of India in South Sudan include:

1. Geopolitical interests which can be explained by its significance to the East Africa region;

2. Energy interests, the essence of which lies is the need of petroleum resources;

3. Agricultural aspects are of particular interest as the developed agricultural sector of South Sudan may contribute to solving India's food problem if productive bilateral cooperation is established.

Although India, unlike China, has no negative experience related to cooperation with Sudan and wants to rival with China in Africa, such perspective does not cause great concern on the Chinese side.

An aspect which facilitates cooperation between Israel and South Sudan is specific historical similarity, which is related to the existence in a "hostile" environment and patronage of the United States of America. Israel's principal interests in South Sudan are:

1. Ability to weaken Egypt in issues related to the distribution of water resources, which is an issue of high priority for Egypt;

2. South Sudan is of great use to Israel in terms of opposing Iran's intentions to gain control of the region. Weapons from Iran are transferred through the Red Sea to Sudan and then to the Sinai and $\mathrm{Gaza}^{2}$. In line with this, Israel's aim is to construct a military base in South Sudan, which might be used for intelligence purposes. On the whole, Israel actively operates in the African region to prevent the influence of Arab countries from spreading; in particular, one of its intentions is to create a union of states in Africa based on the religious pillar, which will stop Islamic influence from growing in the region;

3. Intensification of cooperation with South Sudan will promote restoration and strengthening of Israel's presence on the continent (especially in economic, political, and security spheres);

4. In line with geopolitical aspects, South Sudan is a part of Iran-Turkey-East Africa triangle, which has pivotal importance for Israel ${ }^{3}$.

2 T. Nabili, South Sudan and Israel - Unlikely Allies?, http://www.aljazeera.com/programmes/ insidestory/2011/12/2011122275656217998.html (accessed 19.04.2015).

${ }^{3}$ E. Navon, The Fall of Israel's Last Regional Bastion, South Sudan, http://www.i24news.tv/en/ opinion/140102-the-fall-of-israel-s-last-regional-bastion-south-sudan (accessed 22.04.2015). 
Cooperation between Japan and South Sudan is related to Japan's interest in resources and production capabilities of South Sudan and fits in the framework of "Abenomics": strengthening cooperation with African countries in order to benefit from investments and resources.

For South Sudan as a young state that is in the process of crafting the foreign policy and elaborating a holistic approach to its implementation, the significant positive aspects of cooperation with the Asian countries include the realization of the following foreign policy priorities:

1. Foreign investments attraction;

2. Non-interference in the affairs of other states, promotion of good-neighborliness and mutual cooperation with all neighbor-states and maintaining amicable and balanced relations with other countries.

Implementation of priorities related to foreign investments attraction can be seen in cooperation with Japan, which is caused by the level of economic development of that Asian state. Implementation of this priority includes:

1. LAPSSET funding, which will enable Japan to receive more favorable conditions for further cooperation in the energy sphere. Furthermore, in the future it will lead to a loyal pricing for resources. Moreover, the participation of Japan in the energy sector of South Sudan is unique: unlike China, Malaysia and India, Japan does not have a stake in GNPOC and does not invest in the construction of refineries on Sudan's territory, and this may explain why the company Toyota has decided to invest in LAPPSET: if the project fails, Japan will suffer insignificant losses, but the potential benefits are enormous;

2. Issue a grant for 4 billion yen for improvement of water supply system and construction of infrastructure facilities, such as a river port and bridge over the White Nile.

On the whole, business and investment opportunities spark some level of interest in Israel (including setting up a company in South Sudan in order to create opportunities for Israeli business in the newly established state ${ }^{4}$ ), India, and Russia (organizing series of business forums between the Federal Chambers of Commerce of the aforementioned countries and South Sudan, which were related to railway connection, know-how and electrification, and the signing of relevant documents about cooperation), which can be defined as the initial stage of investment attraction, of which examining business climate and the partner's reliability,

${ }^{4}$ B. Hartman, Potential to Make Money in South Sudan is "Enormous", http://www.jpost.com/Business/Business-News/Potential-to-make-money-in-South-Sudan-is-enormous (accessed 22.04.2015). 
choosing the scope of involvement and the beginning of negotiations process are the relevant features.

Promotion of good-neighborliness and mutual cooperation with all neighborstates and maintaining amicable and balanced relations with other countries is conducted in the following areas: energy (which is a top priority sector), agricultural, and natural resources sectors.

The basis of energy cooperation between South Sudan and the countries of Asia was laid during the existence of a single state of Sudan and intensified after referendum and declaration of independence of South Sudan. India and Malaysia are the most actively involved in this field. At the present stage, India plays a significant role on the oil market of South Sudan: the country is represented by ONGC Videsh Ltd (OVL), which owns 25\% stake in the project GNPOC and $24,125 \%$ in Block $5 \mathrm{~A}$, which produces $5,000 \mathrm{~b} / \mathrm{d}^{5}$ and also has a $25 \%$ stake in $1600 \mathrm{~km}$ pipeline, which begins in South Sudan and connects Khartoum refinery and Port Sudan on the Red Sea ${ }^{6}$. Malaysia is represented by company Petronas, which owns $40 \%$ stake in Block 3 and 7, and 67,875\% share in Block 5A. Japan, Israel and Russia are less involved in the energy sector of South Sudan: Japan's key interest lies in South Sudan's oil with low sulfur content; Israel has initiated negotiations on energy cooperation and investment and Russia takes part in the construction of oil refinery in Bentiumi.

Other areas of cooperation are not as developed as energy sector, but their intensification is important for economic diversification and minimization of risks for South Sudan. The agrarian sector is being developed in cooperation with Israel and India (both of them recognize the potential of South Sudan in agriculture, in particular Israel suggested its model of rural development of African country with the usage of new technologies ${ }^{7}$, and India is willing, in exchange for resources, to develop agricultural areas of South Sudan). Another area is water resources, in which Israel is the most active player, with the following steps being the evidence: signing the Memorandum on cooperation in the field of irrigation, water transport and technological development and a number of other documents, due to Israel's desire to harm the interests of Egypt in the waters of South Sudan.

5 ONGC Shuts Down South Sudan Oilfields, http://businesstoday.intoday.in/story/ongc-shutsdown-south-sudan-oilfields/1/201732.html (accessed 10.01.2015).

${ }^{6}$ R. Modi, India and South Sudan: Potential Areas of Cooperation, http://www.gatewayhouse. in/india-and-south-sudan-potential-areas-cooperation/ (accessed 10.01.2015).

${ }^{7}$ A.K. Leichman, Israel to Build Model Farm in South Sudan, http://www.israel21c.org/socialaction-2/israel-to-build-model-farm-in-south-sudan/ (accessed 10.04.2015). 
The spillover effect plays a pivotal role in intensification of the relations with other countries. It means that the development of cooperation in specific areas can contribute to increasing cooperation in other areas, maintaining friendly relations (which will be based on the economic aspects of cooperation), which will lead to increasing the investments inflow (since the necessary conditions for investments include good investment climate, calm security situation, and a general atmosphere of trust). So it can be concluded that some interdependence between the implementation of the foreign policy priorities of South Sudan exists in a way that the implementation of one priority is an auxiliary method for the implementation of another. This interdependence attests the consistency and the comprehensiveness of South Sudan's foreign policy course.

Thus, in addition to the implementation of foreign policy priorities, South Sudan may get other benefits from the cooperation with Asian countries:

1. Taking into account historical heritage and the lack of atmosphere of complete trust between Sudan and South Sudan, the expansion of military and political cooperation with influential countries will be advantageous for South Sudan as it increases the chances of supporting South Sudan by these countries in case of deterioration of relations with the northern neighbor;

2. The development of alternative economic areas (agricultural and water resources sector) will help to diversify the economy and reduce dependence on energy export, which is of particular importance during the times of unstable security situation;

3. Enhancing cooperation with other countries will reduce dependence on relations with China and the United States, diversifying foreign interactions possibly excludes manipulation techniques during the confrontation between two powerful states.

Realization of foreign policy priorities in cooperation with Asian countries looks promising, but at the present stage it is complicated due to civil conflict in South Sudan, and therefore, in order to protect their own economic interests and investments, some Asian countries occupy an active peacemaking position: in particular, Japan has stepped up its participation in the UN mission in South Sudan by creating a military base for maritime self-defense forces, and on the whole its activity is aimed at finding components of peaceful consolidation, reconstruction, and development. Also Japan refused to limit exports of ammunition to South Korean peacekeepers in South Sudan, provided financial assistance for refugees in the region of Hambella and for improvement of medical care in the three regions most affected by the conflict: Jonglei, Upper Nile, and Unity. In turn, India has intensified its participation in the UN mission in the state of Abyei. All this steps 
can be considered not only as foreign policy steps aimed at strengthening image of states, but as the factor that underlines the interests and importance of South Sudan in the system of foreign interactions of these countries.

1. Cooperation with South Sudan occupies a significant place in the system of foreign interactions of such Asian countries as Japan, Israel, India, and Russia, due to factors of considerable energy resources of South Sudan and the potential in the field of agriculture and water resources, strategic geographical location of that African state, and a desire to strengthen the presence of these countries in East Africa.

2. Cooperation with Asian countries contributes to implementation of two foreign policy priorities of South Sudan: 1) foreign investments attraction; 2) non-interference in the affairs of other states, promotion of good-neighborliness, and mutual cooperation with all neighbor-states and maintaining amicable and balanced relations with other countries. Implementation of the first priority is expressed most fully in cooperation with Japan, and the second - through the development of cooperation in energy (in cooperation with Malaysia and India), agricultural, and water sectors (in cooperation with Israel and India). In addition, the benefits of cooperation with these countries include diversification of exports and expansion of the network of South Sudan's foreign relations.

3. At the present stage, cooperation with South Sudan is at a low level due to the civil conflict in the African state, and therefore, some Asian countries take an active peacemaking position, in particular, intensify their diplomatic efforts and participation in UN Mission and provide financial humanitarian aid to overcome the negative consequences of the conflict. 